This item was submitted to Loughborough's Research Repository by the author.

Items in Figshare are protected by copyright, with all rights reserved, unless otherwise indicated.

\title{
Anniversary Joyce: Introduction
}

PLEASE CITE THE PUBLISHED VERSION

https://muse.jhu.edu/article/736670

PUBLISHER

University of Tulsa

VERSION

AM (Accepted Manuscript)

\section{PUBLISHER STATEMENT}

This work is made available according to the conditions of the Creative Commons Attribution-NonCommercialNoDerivatives 4.0 International (CC BY-NC-ND 4.0) licence. Full details of this licence are available at: https://creativecommons.org/licenses/by-nc-nd/4.0/

\section{LICENCE}

CC BY-NC-ND 4.0

\section{REPOSITORY RECORD}

Van-Mierlo, Wim. 2019. "Anniversary Joyce: Introduction”. Loughborough University. https://hdl.handle.net/2134/36868. 
Anniversary Joyce: Introduction

Wim Van Mierlo

Loughborough University

This special issue comes out of "Anniversary Joyce," the XXV International James Joyce Symposium, which was held in London, 13-18 June 2016.

Anniversaries were in all respects an inevitable theme: the centenary of the Easter Rising and of the publication of $A$ Portrait of the Artist as a Young Man as a Young Man were important events that were marked that year, as well as a host of other anniversaries, Shakespeare's quartercentenary, the centenary of the Battles of the Somme and Verdun; 100 years since Dada erupted and the Cabaret Voltaire was established; the death of Henry James; and the publication of Ferdinand de Saussure's Course de Linguistique generale. 2016 was also the International Joyce Symposium's own golden jubilee: initiated in 1967 in Dublin, the London Symposium was the 25th in the series.1 Celebration and commemoration remain key to the essays that the editors selected for this issue.

For Joyce, 1916 was not an ordinary year. Ensconced since the previous summer in neutral Zurich, where he had taken his family to escape the bombing raids carried out by the Italians on the Triestine port, he was perhaps rather remote from the world's affairs. Yet he was not totally unaffected. We don't have Joyce's recorded response to the terrible events that shook up Dublin during Easter week. On 26 April his friend Francis Sheehy-Skeffington, who had been caught up in a disturbance following a failed public meeting to prevent looting during the Rising, was peremptorily executed at Portobello Barracks on a trumped-charge that he was a ring leader in the Rising. In September, Thomas Kettle, another one of Joyce's Dublin friends and SheehySkeffington's brother-in-law, was killed in the Battle of the Somme.

In Zurich, Joyce was separated from his books and furniture, but not, thankfully, his manuscripts. He engrossed himself in conducting his literary affairs, rendered somewhat more difficult because of the War: unable to travel, and despite the slow and precarious post, he maintained extensive epistolary links with New York (J. B. Pinker), Dublin (Michael Healy) and London (Ezra Pound, Harriet Shaw Weaver and W. B. Yeats). Intent on securing the performance rights for Exiles, he was trying, without success, to get his play staged in London. Meanwhile, with the serialization of $A$ Portrait of the Artist in The Egoist completed, he was also looking for a publisher. Following a series of rejections, the latest one from Duckworth, Joyce accepted Weaver's offer that The Egoist issue the English edition; the New York firm of B. W. Huebsch would publish the book in the US and supply the printed sheets to be bound in the UK. The book appeared just before the year was out, on 29 December.

All in all, the year 1916 was a turning point in Joyce's career. Throughout the year he busied himself, not without a sense of urgency, with getting his old work placed to clear the decks for the writing of the new book, Ulysses (see Letters I, 88). In this he was aided by Ezra Pound, who lobbied on his behalf with friends ("Lady Cunard is your very good friend, she has been trying to stir up ***** to publish you" [78]), publishers and literary magazines ("A new magazine called 'Seven Arts' will probably be glad to print anything you do for a while" [83]). He was also working behind the scenes to secure Joyce a Royal Literary Fund grant; and he gave advice on matters of domestic economy and Joyce's eyesight ("I'd like to see your glasses prescription" [85]). Lastly, he encouraged him to come to London, where he might easily find work with so many men gone to fight in the trenches, but "suppose[d] it is out of the question" (84). It was indeed: Joyce's passport,

1 Between the seventh (Zurich 1979) and the eighth (Dublin 1982), the ordinarily biennial Symposium skipped from the odd to the even years. 
issued by the Consul General in Zurich the previous May, was not valid for travel to England.2 All this activity, on Pound's part as well as Joyce's own, had but one purpose: to establish Joyce's reputation as a writer.

As watershed moment in Irish history and, to a great extent, in Joyce's life and work too, 1916 serves this Anniversary Joyce issue to look again at Joyce's relationship with the Irish Revival. It functions also as a suitable pretext to probe more deeply into Joyce's engagement with acts of remembrance, recollection, and commemoration. Commemoration as a topic is central to both Joyce and Joyce studies. Anniversaries in particular, as is well known, are important. Joyce had an almost superstitious attachment to birthdays and wished for his later books to be published on 2 February. The early Bloomsday celebrations, orchestrated by his friends, were something he was fond of.

The best known of these occasions was the famous "Déjeuner Ulysse," held on the 27 June 1929 at the rustic Hôtel Léopold in Les-Vaux-de-Cernay, south of Versailles, to mark the new French translation by Auguste Morel, Stuart Gilbert and Valery Larbaud. The event is often only remembered for the "two riotous young Irishmen" that were there - Samuel Beckett and Thomas MacGreevy - and for Joyce stopping any speeches (Letters I, 283; JJII 615-16). Though a jovial enough party, it was also quite the "social" occasion. Among the approximately 25 guests ("Two char-à-bancs full of people!" [Letters I, 281]) were several of Joyce's friends, as well as various prominent figures within contemporary French letters, several of whom with connections to either Mercure de France or the Nouvelle revue française. The English-speaking press had been invited as well..3 Besides Léon-Paul Fargue, Philippe Soupault and Paul Valéry, close acquaintances of Joyce's, there was Pierre de Lanux, author and diplomat, and former secretary to André Gide; Marc Chadourne, novelist and translator of Joseph Conrad; André Chamson, novelist and historian; Edouard Dujardin, whom Joyce had not met previously; the poet and writer Jules Romains; Ludmila Savitzky, the Russian émigré author and famous translator of, among others, A Portrait of the Artist; Marie Scheikévitch, another Russian émigré, memoirist and close friend of Marcel Proust; Simone Téry, writer and journalist who reported on the Irish war of independence for the left-wing newspaper L'Oeuvre. The purpose of the lunch was without doubt to ensure that the appearance of Ulysse was noted by the right people. A month later he wrote rather tetchily to Valery Larbaud that Morel and Gilbert had not bothered to show up (Letters I, 280). But on the day, as one can judge from his demeanour on the photo eternalizing the event, Joyce was inordinately pleased with himself.

Joyce's writings, too, abound with commemorative acts, personal and public. Honouring the Misses Morkan, Gabriel's speech in "The Dead" commemorates a private tradition. (The marking of religious feast days is of course an act of remembrance and celebration in its own right.) In $A$ Portrait and Ulysses, we see that public commemorations are mostly experienced personally and privately. For example, when Stephen fantasizes about setting off for home for the Christmas holidays from Clongowes, he imagines seeing how "the drivers pointed their whips to Bodenstown" (P 20). As Luke Gibbons points out, the drivers' silent gesture is significant in its ephemeral aspect,

\footnotetext{
2 Forrest Read, ed. Pound/Joyce: The Letters of Ezra Pound to James Joyce, with Pound's Critical Essays and Articles about Joyce (New York: New Directions, 1967), 78, 83, 85, and 84. The name omitted from Pound's letter to Joyce about Lady Emerald Cunard is that of the publisher William Heinemann. Joyce's family passport, issued by the Consul-General in Zurich on 10 August 1915, was sold as Lot 91 in the Sotheby's English Literature sale on 14 July 2011. It is reproduced in the catalogue, see $<$ http://www.sothebys.com/en/auctions/ecatalogue/2011/english-literature-history-childrens-booksillustrations-111404/lot.91.html>.

3 Brenda Maddox, Nora: A Biography of Nora Joyce (London: Minerva, 1990), 328.
} 
as they point to the location of Wolfe Tone's final resting place. 4 In this volume, So Onose discusses how at this time the location had become a popular pilgrimage site for nationalists (p. xxxx). A politics of nostalgia equally pervades "Ivy Day in the Committee Room" in which a group of party workers in the privacy of a back room honour Parnell's memory. They have not come together specifically to celebrate the dead leader; it so happens that, due to the atrocious weather, instead of being out canvassing for the municipal elections, they spent most of their time inside whiling away the time by the warm file the Royal Exchange Commitee Room in Wicklow Street. This makes the gathering all the more poignant, as they gripe about the shoneens, criticize Mr. Tierney, the candidate they are working for, and reminisce about the good old days under Parnell.

All these instances show the power of the shared memory for Joyce and its importance for the community. Yet he also remains wary of heroic aggrandizement and the false public sentiments that go with it, particularly when it comes to the monumentalizing of the Irish past. 5 The contrast between the instances of commemoration that I have listed in the previous paragraph and the starkly bleak description in A Portrait of the laying of the foundation stone for Tone's statue (also discussed by Onose in this issue) on the corner of St. Stephen's Green and Grafton Street during the ' 98 centenary celebrations should therefore come as no surprise:

In the roadway at the head of the street a slab was set to the memory of Wolfe Tone and he remembered having been present with his father at its laying. He remembered with bitterness that scene of tawdry tribute. There were four French delegates in a brake and one, a plump smiling man, held, wedged on a stick, a card on which were printed the words: Vive Irlande. (P 184)

In the moment, the event was perhaps all-too solemn and ridiculous. The foundation stone was formally laid by no less than John O'Leary who "laid the stone, with a tap for America, for France, and one for each of the four provinces." 6 The tawdriness of the patriotic display, and Stephen's disappointment with it, form a startling contrast with the exuberance with which the newspapers of the time reported on the events. The Freeman gushingly called it "[a]thrilling scene" as businesses had closed for the day and "scores of thousands" lined the streets to watch the procession, which progressed from Rutland Square, past Tone's birthplace in Stafford Street and St. Michan's, where the Brothers Sheares and (allegedly) Robert Emmet are buried, to the corner of Stephen's Green at Grafton Street.7 The orations, including that by a young W. B. Yeats, all noted that the spirit of nationalism and the "unextinguishable fire of patriotism" was as alive in 1898 as it was in Tone's day, and that England would have to reckon with this; John Redmond called for the formation of "a great, broad national platform," for Protestants and Catholics to come together in "one united nation," so that one day the people might "celebrate the realisation for which Tone died." 8 Stephen's cynicism is perhaps surprising, though, because the appearance of John Dillon and John Redmond on the same platform signalled, as Maud Gonne disappointedly believed, the triumph of the constitutionalists in the struggle for self-determination. 9 For Onose the watering down of the

4 Luke Gibbons, “'Where Wolfe Tone's Statue Was Not': Joyce, Monuments and Memory.” In History and Memory in Modern Ireland, edited by Ian McBride, 139-59 (Cambridge: Cambridge University Press, 2001), 148.

5 Anne Fogarty, “'Stone Hopes': Statues and the Politics of Longing in Joyce's Work," Dublin James Joyce Journal 1 (2008): 75.

6 Freeman's Journal, 16 August 1898, 6.

7 Freeman 's Journal, 16 August 1898, 5.

8 Freeman's Journal, 16 August 1898, 6. See also The Collected Letters of W. B. Yeats, vol. 2: 1896-1900, edited by Warwick Gould, John Kelly and Deirdre Toomey (Oxford: Clarendon Press, 2000), 704-705 and R. F. Foster, W. B. Yeats: A Life, vol. I: The Apprentice Mage, 1865-1914 (Oxford: Oxford University Press, 1998), 195.

9 See Senia Pašeta, “1798 in 1898: The Politics of Commemoration," Irish Review 22 (1998): 50. 
radical spirit of nationalism is an important element in his argument for Stephen's own Toneite revolutionary allegiances (p. xxxx). But no doubt, Stephen's feelings too reflect those of his father who felt abjectly wounded by the betrayal of Parnell and the subsequent split in the Irish Parliamentary Party. The feeling of political paralysis, in other words, which father and son believe pervades the nation at the turn of the century colours Stephen's experience.

Ulysses, by comparison, much more directly critiques the idea of shared cultural memories. Shared by whom exactly? The argument between Bloom and the Citizen in "Cyclops" about "the old guard and the men of sixtyseven" and "ninetyeight" ( $U$ 12.480-81) - the failed Fenian Rising of 1867 and the 1798 Rebellion led by Wolfe Tone - is an argument about the proper way of remembering. Bloom is naturally concerned with inhumanity of it all (or so we surmise, for the Cyclopean narrator does actually not give us Bloom's view); the Citizen meanwhile jabbers on about "[dying] for your country" and "[t]he memory of the dead" ( $U 12.500$ and 519), defending the ultimate sacrifice in which the nation's cause is put ahead of the life of the individual. The Citizen's glorification of violence has a redemptive force, but acts of memorialization are selective in what they remember and how they serve identity. Commemorative events are as much about building community as it is about separating out from that community those who do not share its beliefs. This what the Citizen does with Bloom as he shuts up his adversary, who is trying to make a final point, with the rallying cry: "Sinn Fein! Says the citizen. Sinn fein amhain! The friends we love are by our side and the foes we hate before us" $(U 12.523-24)$. This final retort ends the dispute and appropriately segues into the passage that is usually understood to refer to Robert Emmet's public execution.

The parody of the events of Emmet's final moments may owe much of its sardonic effect to the manner in which the execution is staged: as a public spectacle it could well be (or at least double as) a commemorative re-enactment of Emmet's hanging.10 Several anachronisms in the passage may support the idea that this may be more than a hyperbolic account of the actual hanging. The Dublin Metropolitan Police and the Royal Irish Constabulary, who are called in to control the crowd, were not formed until 1836 and 1822 respectively. Nor would there have been "[s]pecial quick excursion trains and upholstered charabancs" $(U$ 12.539-40) to bring in the hordes of spectators from the country.11 Furthermore, the Citizen's allusion in the preceding exchange with Bloom to the "Memory of the Dead," a song by John Kells Ingram whose opening line runs "Who fears to speak of Ninety-Eight?", is further evidence as well. The same song was struck up by the band in 1898 after the formal laying of the Wolf Tone foundation stone was completed; it was played, too, when during the Emmet commemoration in 1903 the procession passed the Green Street courthouse, where Emmet had been tried..12

It may be apparent, then, that it was the public celebrations for the centenary of Emmet's death that Joyce had in mind. As it happened, the 1903 commemoration was far more theatrical than the events of the ' 98 centenary had been. The parade, which followed the route from Stephen's Green where Emmet was born to Thomas Street, included among others a group of barefoot and ragged children from the poorer districts carrying homemade pikes and wearing green hats. The Irish National Foresters were led by members of the Robert Emmet Costume Association in "full Emmet

\footnotetext{
10 Cóilín Owens, “The Charity of Its Silence': “After the Race' and the Emmet Centenary,” Dublin James Joyce Journal 1 (2008): 34.

11 For the actual 1903 centenary event, the railways took great effort to accommodate the number of people travelling to Dublin, see Marianne Elliott, Robert Emmet: The Making of a Legend (London: Profile Books, 2003), 19.

12 See Don Gifford and Robert J. Seidman, Ulysses Annotated: Notes for James Joyce's Ulysses (Berkeley: University of California Press, 1989), 275; Freeman's Journal, 16 August 1898, 6; and Elliott, 194. Thomas Street, the location where Emmet was executed, later became a pilgrimage site where mock funerals were held, see Elliott, 151.
} 
uniform.".13 Elsewhere, local organizations put on tableaux and dramatizations of Emmet's life. 14 The reason why the Emmet celebrations seemed so much more camp has everything to do with the the romanticization of Emmet as a hero. Wolfe Tone, who took his own life when the British refused him a military execution by firing squad, was the ultimate symbol of self-sacrifice; Emmet, always the theatrical man himself dressed in his white-and-green uniform, Hessian boots and a feathered cocked hat, who was hung, drawn and quartered represented so much more than a martyr's death. For Joyce, the hero's violent execution and the carnivalesque appearance of the celebrations provided the perfect occasion to transmute the memory of his death into a blood spectacle that the rabble can enjoy.

To understand the impetus behind the Emmet parody as commemoration, it is relevant to look at the significant reinterpretation that the "Cyclops" chapter as a whole and the figure of the Citizen in particular has undergone in the criticism. Emer Nolan has argued that the traditional view of the Citizen as a rabid nationalist bigot is in fact a reductive reading reflective of the biases of liberal academics; she contends instead that close parallels exist between the Citizen's politics and Joyce's own responses to Irish nationalism. Following on from her, Andrew Gibson argues that Joyce not so much takes sides as "understands the citizen (historically) [...] by placing him in a particular discursive context"; as Gibson furthermore demonstrates, the Citizen's rhetoric and the discourses in the parodies converge quite closely. 15 His reading of "Cyclops" therefore highlights not just how replete with "[h]istorical particularity" that chapter is, but how these particularities compete and jostle with one another in a manner that does not permit a single viewpoint. 16 As a memorial project in its own right, Ulysses is not a mouthpiece of an individual experience (the way $A$ Portrait perhaps still was) but encloses within its all the delights and unpleasantness of human history. If with this in mind one understands the parodic account of Emmet's death as an execution turned into spectacle, then the passage exposes the complicity and hypocrisy of the spectators in the violence. However, if one understands it as a commemoration, then the passage provides a vision, albeit a grotesque one, of an Ireland united, for among the "five hundred thousand persons assembled" ( $U$ 12.534) are people from all walks of life: country people, orphans, a pastor, the Lord Lieutenant of Ireland and his houseguests, a foreign delegation of notables, Emmet's fiancée, a "handsome young Oxford graduate" ( $U$ 12.659), and a score of burghers. Not coincidentally, the crowd is described as a "monster audience [that] simply rocked with delight" ( $U$ 12.650-51); the carnivalesque behaviour of the crowd and its concomitant mongrelization betrays a deeply ambivalent attitude towards popular hero worship and their commemoration.

Contrary to received opinion, Joyce's views on the Easter Rising may have followed a similar trajectory as that of the country as a whole. When the tide of opinion shifted following the heavyhanded British reprisals and execution of the leaders of the Rising, the idea of using force to end British rule was no longer a marginal notion; the direct connection between the outcome of the Rising and the War of Independence two years later is a well-established fact in Irish historiography..17 Is it possible, then, that Yeats's "terrible beauty" found its resonance with Joyce? Joyce's invocation of the Rising in Finnegans Wake, which, like Ulysses, purports to contain all of history, seems uncharacteristically anodyne for a writer normally opposed to violence, a point that Greg Winston explores in this issue as well. As Winston notes, Book IV opens with a call to resurrection/insurrection: "Calling all downs. Calling all dawns to dayne. Array! Surrection!"

\footnotetext{
13 Elliot, 194.

14 Owens, 32-33.

15 Emer Nolan, James Joyce and Nationalism (London and New York: Routledge, 1995), 100, and Andrew Gibson, Joyce's Revenge: History, Politics, and Aesthetics in Ulysses (Oxford: Oxford University Press, 2002), 124-25.

16 Gibson, 123.

17 White Timothy J. and Denis Marnane, "The Politics of Remembrance: Commemorating 1916," Irish

Political Studies 31, no. 1 (2016): 35, https://doi.org/http://dx.doi.org/10.1080/07907184.2015.1126930.
} 
( $F W 2010463.02 ; F W$ 593-02-03), a passage that Winston refers to as well. A few lines down it is followed by: "Sonne feine, somme foehn avaunt! Guld modning, have yous viewsed Piers' aube?" (FW2010 463.07-08; FW 593-08-09). The new dawn is one that starts with Pearse's soap, but it is also Pearse's dawn (Fr. aube) or rising: it was Pádraig Pearse it who gave the signal to start hostilities on Easter Sunday; it was he who read the Proclamation of the Irish Republic outside the GPO. The Easter Rising in the Wake becomes part of its preoccupation with millenarianism, the abrupt transition from one epoch to the next. A later passage in Book IV appropriately questions beginnings and endings, forgetting and remembering:

What has gone? How it ends?

Begin to forget it. It will remember itself from every sides, with all gestures, in each our word. Today's truth, tomorrow's trend.

Forget, remember!

Have we cherished expectations? Are we for liberty of perusiveness? Whyafter what forewheres? [...]

Forget! (FW2010 481.01-08; FW 614.19-26)

Its typical probing into origins - what has gone before? what came after? - is an admonishment to forget, but although remembering in the Wake is always woefully flawed and inadequate, forgetting by the same token is impossible. History may be a "wholemole millwheeling vicociclometer," the past cannot be eradicated; its "heroticisms, catastrophes and eccentries" are perpetually, uinterruptedly, unstoppably "transmitted by the ancient legacy of the past," including the "all-tooghoulish and illyrical and innumantic in our mutter nation, all, anastomosically assimilated" (FW2010 481.09, 16-17, 20-21; FW 614.27, 614-35-615.01, 615.04-05). Encapsulated with the final rendition of the famous Quinet sentence, the book here commemorates Ireland's violent and unpoetic history; cleverly, Joyce weaves in three ancient places - Gaul, Numantia and Illyria noted for their resistance to the Roman colonizer, while he ironically notes the anastomosis and assimilation of the nation's different parts. The creation of the Irish Free State, which resulted in the separation of the northern counties from the rest of the country, was of course the exact opposite: not a connection, but a disconnection, between adjacent parts. Yet the Wake re-enacts (as in reprises) the armed resistance to British rule counter-historically realizing the historical possibilities that the '98 commemorations had prophesied: a United Ireland. Thus Joyce implicitly draws a direct line from Wolfe Tone to the Easter Rising and the War of Independence.

As Joyce's writings amply demonstrate, Ireland has a rich and interesting legacy in cultural commemorations of significant historical events, beginning with the centenary celebrations of 1898 up to the 2016 commemoration of the East Rising. Joyce's own legacy has become part of this long history of commemoration too in the form of annual Bloomsbury celebrations worldwide and his central place in Ireland's literary heritage. It is opportune therefore, as this special issue does, to look more closely at a culture of commemoration and legacy, within the critical sphere of cultural memory and psychogeography, as it pertains to Joyce's life and work, and their reception.

The essays in this encompass three related themes: (1) anniversaries and commemorations; (2) legacies and heritage; (3) psychohistories and psychogeographies. Each of these pieces explores questions about the nature of the history in relation to Joyce: how the past is interpreted and remembered in or by Joyce's writings? How it engenders Joycean legacies. And how these legacies are written back into the culture (including, but not limited to, Irish culture) and in turn inflect that past?

Commemoration is a multi-modal act. The event itself is first of all "very likely not something about which there is consensus in terms of interpretation": the changing worldviews that come about in the period that separates the time in which the event took place from the moment it is 
remembered is characterized by changing worldviews and perspectives make interpretation and understanding of the event quite problematic..18 Furthermore, competing agendas of commemoration may be at work as well, particularly insofar as commemoration involves a validation of the past, which means entering into equally contestable territory. 19 Owing the politics of selection and inclusion that are at play, commemorative celebrations therefore often become contentious affairs. Writing at the start of 2016, White and Marnane speculated for instance whether the official 2016 Easter Rising Commemorations would "want to celebrate the violence that was associated with the achievement of independent Ireland." 20 Similarly, problems of non-inclusivity and alienation plagued the '98 Centenary Committee when it started its work in 1897 to remember the United Irishmen Rebellion led by Wolfe Tone. An editorial in the Irish Examiner was just one of many that complained about the "[i]ll-advised action" by certain members of the organizing committee that "imparted [...] a narrow and sectional character quite inadequate to the national demand and aspirations." 21 Much of the in-fighting, as the editorial suggests, was between factions within the Irish Parliamentary Party, but there was concern as well that an outspoken Fenian inflection would dominate the memory of a patriotic movement that had set aside sectarian differences to fight for a common cause. 22 Conversely, the confirmation of Tone as "unrivalled icon of resistance" is believed to have led to radicalizing a nation that now once again aspired to become independent. 23

The upshot of all this is that we are not just concerned with what the past means, but how it means. This is the domain of cultural memory, which (as Ian McBride puts it in the context of Irish history) is concerned with "the relationship between the past and the present" and "the ways in which historical consciousness has been shaped and structured by oral tradition, icons and monuments, ritual ceremonies and re-enactments." 24 Underlying McBride's point is the notion of the lieu de mémoire, the "concrete" "spaces, gestures, images, and objects" in which, according to Pierre Nora, memory anchors itself. 25 While Nora's notion is useful in terms of gauging the affective quality of memory, which is important for the understanding of the contested histories of identity and nationhood, he essentially supports a dualistic system in which history, as an intellectual discipline, sits at the opposite end of memory encapsulating real, lived experiences. Recognizing that there is a dialectic between memory and past, Richard Terdiman, by contrast, considers memory intangible but no less real; but instead of the thing remembered, he highlights the cognitive and emotive process behind remembering. In his formulation, recollection is an act which makes the past present; thus, "[m]emory is the modality of our relation to the past." Hence, when we accept that the past is constructed, memory is "[ $\mathrm{t}]$ he agent of that construction." 26

In her introduction to Memory Ireland: James Joyce and Cultural Memory, Oona Frawley similarly emphasizes the processual nature of memory and how Joyce's works and his characters "reflect on

\footnotetext{
18 White and Marnane, 30.

19 White and Marnane, 30.

20 White and Marnane, 38.

21 Untitled, Irish Examiner, 8 November 1897, p. 4. W. B. Yeats, as Chair of the '98 Executive of Great Britain and France, contended with similar issues from those who sought to impose "a party character" on an "occasion well calculated to knit all Irishmen together in bonds of unity and nationhood" (Yeats, Letters II, 181).

22 See Foster, 189. As Foster indicates, though, Yeats had increasingly become embroiled with the more radical Irish National Alliance. See also Pašeta, 47.

23 Ian McBride, "Memory and National Identity in Modern Ireland." In History and Memory in Modern Ireland, edited by Ian McBride, 1-42 (Cambridge: Cambridge University Press, 2001), 2 and Pašeta, 52. 24 McBride, 4.

25 Pierre Nora, "Between Memory and History: Les Lieux de Mémoire," Memory and Counter-Memory, Special Issue of Representations 26 (1989): 8, <http://www.jstor.org/stable/2928520>.

26 Richard Terdiman, Present Past: Modernity and the Memory Crisis (Ithaca and London: Cornell University Press, 1993), 7-9.
} 
and deliver analyses of history." 27 Like other work on cultural memory - by Anne Fogarty, Luke Gibbons and Rita Sakr among others - the volume edited by Frawley and O'Callaghan extends the historical turn that happened in Joyce studies in the 1990s and shifts the focus from its original historiographical concern - how Joyce understood the past - to a more fine-grained analysis concerned with how he used and responded to the past. 28 Anniversary Joyce builds on this work. Consequently, this special issue is concerned with recollection - and refraction, reconnection, (re)appropriation, reconstitution - of the past, focusing specifically on acts of commemoration, memorialization and the creation of legacies.

This epistemic cycle - or recycling - is, this special issue will argue, central to Joyce's work. Finnegans Wake most explicitly realizes the recycling of history. The book's theme is memory, the impossibility of remembering, while Dublin/Irish/European/World history is rewritten, mashed up and inscribed anew. The peripatetic wanderings in Ulysses constitute a vast psychogeography. Joyce's novel meshes coincidences of city, culture, past and present. In it Joyce dramatizes how the Irish past, in the first instance its colonial past, are an unavoidable presence and how his characters respond, emotionally and politically to that past, and thereby give it shape and meaning. The issue will look at specific moments and events in history, including those of 1916, and how they are refracted through Joyce's writing.

While the cataclysmic events of the Great War and the Easter Rising have already received some attention from scholars, it is timely to investigate Joyce's relation to them in greater critical depth. (As various papers at the London Symposium demonstrated, Joyce's work is far more concerned with these events than critics generally recognize.) The issue opens with Brian Fox" "Sots, Songs, and Stereotypes: 1916, the Fighting Irish, and Irish-American Nationalism in Finnegans Wake," a detailed study of the Irish reputed predilection for violence. His essay focuses on how Joyce incorporated this stereotype in Finnegans Wake, whose title foregrounds the drunken brawl motif in its allusion to the famous Irish-American fighting song of the same name. Although Fox considers why the stereotype of the fighting Irish was "embraced or absorbed as a national self-image" (p. $\mathrm{xxxx}$ ), he is particularly concerned with forms of Irish-American violence. While there is a parallel between the spirit that led to American independence and the United Irishmen's armed campaign to deliver Ireland from British rule, the generally more moderate tone of republican discourse at home stands in stark contrast to the hardened nationalism of American Fenians who advocated blood sacrifice. Ultimately, however, the Fenian idea and its martial rhetoric, and the vast amounts of money raised in support of the IRB as a result of it, were a contributing factor in the unleashing of the dramatic events of 1916. Fox reminds us, furthermore, that no less than five of the seven individuals who signed the Proclamation - Clarke, Connolly, Plunkett, MacDonagh, and Pearse maintained extensive links with revolutionaries in the US and had direct contact with them in the run-up to the Rising. Joyce, as is well known, believed that "violence breeds violence" (p. xxxx), and in his Triestine lectures he explored some of the historical realities that lay at the basis of the reputation that the Irish are endemically violent. It seems history is to blame. Fox is careful, however, not to read this as an easy apology. Instead he argues that "Joyce, rather than endorsing any idea of inherent racial characteristics making the Irish especially pugnacious, points to a form of historical memory instead" (p. xxxx). In other words, Joyce seeks to deflate the caricature by considering it the legacy - and a response to - a long history of systemic violence imposed from the outside. Fox' reading of Finnegans Wake, therefore, in which violence is not hard to find, hinges

27 Oona Frawley, "Introduction: James Joyce, Cultural Memory, and Irish Studies.” In James Joyce and Cultural Memory, edited by Oona Frawley and Katherine O'Callaghan, 1-9 (Syracuse: Syracuse University Press, 2014), 1.

28 See, for instance, Oona Frawley and Katherine O'Callaghan, eds. James Joyce and Cultural Memory (Syracuse: Syracuse University Press, 2014); Luke Gibbons, Joyce's Ghosts: Ireland, Modernism, and Memory (Chicago: University of Chicago Press, 2015); and Rita Sakr, Monumental Space in the PostImperial Novel (New York and London: Continuum, 2012). 
upon a "relentless comic deflation" of violence and its redemptive legitimizations as it heralds "a profound concern about the commemoration and legacy of violence itself" (p. xxxx).

Writing about $A$ Portrait, So Onose tantalizingly recasts Joyce's fictional autobiography "as a 'republican' Bildungsroman which chronicles Stephen's growth into a young rebel who models his life after that of the United Irishman Theobald Wolfe Tone" (p. xxxx). Onose starts his contribution with a consideration of the '98 Centenary and the laying of the Foundation stone for Tone's monument on 15 August. As he carefully traces Stephen's Toneite allegiances, Onose addresses the question, and formation, of Stephen's political position - Fenianism or constitutional reform regarding the way to Irish independence. Significantly, Onose portrays Stephen not simply as a follower of his father's brand of nationalism, but suggests instead that Stephen's opinion owes something to the political beliefs of his great-grandfather, John Stephen Dedalus, a condemned whiteboy $(P 38)$. Thus Onose gives Stephen's political awakening, and his identification with Tone as a patriotic figure, a greater degree of agency and independence than has hitherto been recognized.

Greg Winston returns to the theme of violence in Irish history in "Queensberry Rules and Jacob's Biscuits: James Joyce's Easter Rising” which investigates even more directly than Fox Joyce's attitude towards the Rising and its effects by laying bare significant mentions of the Rising "in sometimes partially veiled, figurative constructions" in Ulysses and Finnegans Wake (p. xxxx). His aim in doing so is to counter the received idea that Joyce's objections to the Rising (and to the War of Independence and the Civil War) were "rooted in his pacifism" (p. xxxx). To be clear, Winston does not want to argue that Joyce was not a pacifist; nevertheless Joyce's writing does not (as Fox too argued) unequivocally eschew or reject violence. Pointedly, on being asked his opinion on the prospect of an independent Ireland, Joyce purportedly said that he might "declare myself its first enemy" (JJII 411-12). The language of Ulysses and Finnegans Wake is pervaded with metaphors of violence, often in the form of catachresis - "an intentional misuse or mixing of metaphors," what Winston calls "forced metaphor" (p. xxxx). In a closely-knit analysis, Winston argues that the Keogh-Bennett boxing match (which applied the still fairly-new code developed by John Douglas, the Marquess of Queensberry, which among others forbade hitting below the belt) extensively alluded to in "Cyclops" and the Citizen's hurling of the Jacob's biscuit tin after Bloom are metaphoric extensions of Pearse's rhetoric of "holy nationalism" (p. xxxx). The point of this is not to create a coincidental, if not spurious, link between blood sports and the Rising; for one, Winston reminds us that sports have long served as "a forced or mixed metaphor" in the arena of armed conflict and British imperialism. Rather, he insists that the sacrificial language of the official rhetoric of the Rising itself was couched as forced metaphor, and thus undeniably suspect in its multiplicity and ambivalence. It is this, Winston argues, that Joyce exposes.

The reception history of Joyce's has been meticulously documented.29 The question of his legacy, however, which too involves acts of remembering and commemoration, provides an opportunity to look anew at his lasting significance on critical and creative practices, and on culture as a whole. With his position within the literary pantheon fully ensured, we are not just considering his influence or his place within the canon, but his status as a cultural icon and what that means. How do later generation of writers, thinkers and artists confront, adapt and re-use his work? How does literary heritage operate to memorialize Joyce? In this issue, John McCourt and John Nash address some of these questions.

29 See Joseph Brooker, Joyce's Critics: Transitions in Reading and Culture (Madison: University of Wisconsin Press, 2004); Geert Lernout and Wim Van Mierlo, eds. The Reception of James Joyce in Europe (London: Continuum, 2004); and John Nash, James Joyce and the Act of Reception: Reading, Ireland, Modernism (Cambridge: Cambridge University Press, 2009). 
McCourt's essay, "Reading Ulysses in Ireland in the Twenties," makes an important contribution to our understanding of the early reception of Joyce's major work in his native country. Unlike earlier considerations of the negative reviews published in the Irish press, McCourt's essay not only pays attention to those Irish critics and intellectuals who wrote supportively of Joyce's work, he emphasizes the "political implications for Ireland" which the early reactions - positive and negative - identified and commented on. As McCourt writes:

These early Irish Joyceans - although rarely seen as anything other than an eccentric and marginal part of the international critical field - were, in fact, in many ways, ahead of that same field in their reading of Joyce in the light of their various own Irish political and religious backgrounds and preoccupations: Anglo-Irish, Unionist, Catholic, Protestant, Nationalist, disaffected Nationalist or a hybrid mixture of various of these options. (p.xxxx)

That these early commentaries were "significantly affected and even compromised" by the concurrence of the book's publication with the outbreak of the Civil War is a fact which, for McCourt, almost speaks for itself.

John Nash, looking in at the other end of the telescope, offers an augmented interpretation of the attitudes of T. S. Eliot to Joyce's work on the basis of Eliot's teaching notes from his Harvard year in 1932/33. In the notes, Nash observes a substantial shift in Eliot's appreciation from what he calls "the buttoned-up Eliot of 'Ulysses, Order and Myth": one is the "determinedly personal, even emotional" approach to reading Joyce; the other is the acknowledgement of the "distinctively Catholic" element in Joyce (p. xxxx), the exploration of which reveals a significant moment in Eliot's development prefiguring the ideas from After Strange Gods (1934). Existing in a liminal space between private and public, the teaching notes show an uncharacteristically unguarded Eliot (and in this lies their significance) as Eliot works through a meticulous comparison of Joyce's Irish Catholicism to D. H. Lawrence's English non-conformism and of the class differences between them. Eliot's preoccupation with the "Catholic idea" in Joyce - Eliot found that Joyce was primarily "concerned with the relation of man to God" (quoted at p. Xxxx) - leads Nash to speculate that Eliot may have been working through aspects of his own faith. What Joyce's legacy is concerned, therefore, Eliot's religious considerations put into question the supposition that modern literary criticism after F. R. Leavis is largely "conducted within a generally secular framework" (p. xxxx); such a framework may be critically and historically distorting. The importance of the notes, Nash concludes, therefore also lies in how they underscore the need to understand Joyce "within the religious contexts that affected both his writing and its reception" ( $\mathrm{p} . \mathrm{xxxx})$ - to which one might add that the same holds for Eliot whose Anglo-Catholic worldviews have not yet been subject to any historical contextualization either.

Commemoration as an exploration of and engagement with past events must also closely align itself with an exploration of past places. As forms of cultural memory, psychohistory and psychogeography can blend an investigation of present topographical experiences with an exploration of the past. The final essay in this special issue, Katherine O'Callaghan's "The Riddle of the Brocken Spectre: Reading Finnegans Wake on the top of Croagh Patrick," is a deep reading of the "cultural, geographic, and topographic coincidences" of St. Patrick's sacred mountain in Joyce's final work that link with "a particular Irish clash of civilizations with a universal pattern of conflict and usurpation" (p. xxx). Running through the various iterations of Croagh Patrick in the Wake, O'Callaghan carefully constructs an argument about the site as a primal scene for the colliding of different worldviews: pagan and Christian, obviously, but also superstition and science. The Brocken, which in German folklore is a magic location, features in the Wake as a double for Croagh Patrick because, when weather conditions are right, both are locations where the Brocken spectre can be observed, the illusion of a spectral giant which is in reality the shadow cast by one's own body into the mist. For O'Callaghan, the double nature of the spectre in the landscape 
represents both "uncanny nature of the projection of the self into the world" and "the encounter with the other" that are central to all acts of storytelling and mythmaking, not in the least the Wake's.

By focusing on commemoration and recollection, Anniversary Joyce adds a new voice to the discussion of Joyce and cultural memory. The contributors in this volume have applied new perspectives, connections, synchronicities and iconographies, and in some cases have used new archival sources. Much is yet to be gained, however, from the application of cultural memory and psychogeography as a critical and scholarly lens. Both are important and exciting fields of interdisciplinary inquiry that link history, psychology, literature, politics and sociology, areas with which Joyce's work is closely concerned. We hope that by setting out a new direction as we have done our issue may stimulate future inquiries into these subjects. 